\title{
The hydrogen economy and jobs of the future
}

\author{
Roger H. Bezdek* \\ Cavendish Energy LLC, 2716 Colt Run Road, Oakton, Virginia, USA
}

Accepted: 30 November 2018

\begin{abstract}
Growth in the hydrogen and fuel cell industries will lead to vast new employment opportunities, and these will be created in a wide variety of industries, skills, tasks, and earnings. Many of these jobs do not currently exist and do not have occupational titles defined in official classifications. In addition, many of these jobs require different skills and education than current jobs, and training requirements must be assessed so that this rapidly growing part of the economy has a sufficient supply of trained and qualified workers. We discuss the current hydrogen economy and technologies. We then identify by occupational titles the new jobs that will be created in the expanding hydrogen/fuel cell economy, estimate the average US salary for each job, identify the minimum educational attainment required to gain entry into that occupation, and specify the recommended university degree for the advanced educational requirements. We provide recommendations for further research.
\end{abstract}

\section{Introduction}

In the countless volumes written in recent years about the emerging hydrogen $\left(\mathrm{H}_{2}\right)$ economy, very little has focused on the requisite $\mathrm{H}_{2}$ jobs and corresponding education, skills, and training required and the likely earnings that can be expected. Here we remedy this by

- reviewing the current state of the hydrogen economy and hydrogen technologies;

- identifying the unique occupational titles of the new jobs that will be created in the hydrogen energy economy;

- specifying the most important qualifications and skills that employers will be seeking;

- estimating the average US salary for each job;

- identifying the minimum educational attainment necessary to gain entry into each occupation; and

- specifying the recommended university degree for the advanced educational requirements.

\section{Hydrogen economy and hydrogen technologies}

\subsection{Hydrogen economy}

Hydrogen has the distinction of competing with nuclear fusion as the energy technology that is "always in the future." Consider the following:

\footnotetext{
* e-mail: rbezdek@cavendish-e.com
}

- In 1960, a reputable engineering magazine predicted widespread military use of hydrogen fuel cells (FCs) in about 3 years and industrial use in 5 years [1].

- In the mid-1970s, the US Energy Research and Development Administration published reports predicting the imminent arrival of the hydrogen economy [2].

- In 1998, Iceland, in cooperation with German and Canadian firms, announced a 10-year plan to create a hydrogen economy and convert all transportation vehicles, including Iceland's fishing fleet, to FC power [3]. - A decade ago, the world was "on the cusp of a fuel-cell revolution": Hydrogen FC-powered vehicles were poised to dominate the market and cheap, clean hydrogen power would be available for numerous other applications [4].

Of course, none of this happened. Why not? What are the current prospects for the hydrogen economy? What are the viable hydrogen technologies?

While the hydrogen economy has not arrived, hydrogen is nevertheless a big business and is growing rapidly. As an industrial gas, hydrogen is already a huge global industry with strong fundamentals and favorable prospects. The global hydrogen market is forecast to increase $\$ 33$ billion over the next 4 years, from US $\$ 122$ billion in 2018 to US $\$ 155$ billion in 2022 . This is a growth rate of $33 \%$ over this period - a compound annual growth rate of over $6 \% / \mathrm{yr}[5]$. The world market is expected to grow rapidly due to government regulations for desulfurization of petroleum products and increasing demand for hydrogen as a clean transportation fuel [6]. 
Hydrogen is currently required in the refining industry as a petrochemical for hydrocracking and desulfurization. During petroleum refining, hydrogen is used for desulfurization, and thus the requirement for hydrogen in refineries depends on the sulfur level present in petroleum products. Governments are regulating sulfur content in final petroleum products, and the demand for hydrogen in refineries is increasing rapidly.

Hydrogen is used in large quantities for chemical product synthesis, especially to form ammonia and methanol, and is used as an agricultural fertilizer. It is also used for applications in metal production and fabrication, methanol production, food processing, cosmetics, electronics, FCs, engines and turbines, and energy storage. About $55 \%$ of the global hydrogen demand is for ammonia synthesis, $25 \%$ in refineries, and $10 \%$ for methanol production. The other applications worldwide account for about $10 \%$ of hydrogen production [7].

The hydrogen market comprises two segments: "merchant" hydrogen - i.e., hydrogen generated on-site or in a central production facility and sold to consumers by pipeline, bulk tank, or cylinder truck delivery - and "captive" hydrogen - hydrogen produced by the consumer for internal use at the point of consumption. Captive hydrogen currently comprises about $95 \%$ of the market. However, the US market for merchant hydrogen exceeds $\$ 4$ billion annually and is growing about $7 \% / \mathrm{yr}$, while the US market for hydrogen power systems is about $\$ 3.5$ billion and growing nearly $10 \%$ annually [7].

Captive hydrogen production is expected to dominate the market until 2021. However, merchant production is forecast to increase in market share because of the effective technologies used by manufacturers in the market - the most common technologies used worldwide include electrolysis (water) and reformation (methane). North America is the largest market for merchant hydrogen.

\subsection{Hydrogen technologies}

At present, nearly all industrial hydrogen is produced or "reformed" from methane in fossil energy, primarily from natural gas, although oil and coal are also used. The relatively low price and increasing availability of natural gas imply that it will be increasingly used to meet the growing world demand for hydrogen. It thus appears that hydrogen production will be an increasingly important driver of natural gas demand.

The production of hydrogen at commercially viable prices has been very difficult to achieve. As noted, talk of a move to the "hydrogen economy" was largely premature and most previous hyperbolic claims for hydrogen applications neglected to account for the market price and highly limited availability of the hydrogen. FCs, internal combustion engines using hydrogen (or adding it as a "sweetener"), and many other potential applications are economically limited by the input price for bulk hydrogen production, storage, transport, and safe handling.

The two most common sources of industrial merchant hydrogen, electrolysis and steam reforming of methane/ natural gas (with approximately $5 \%$ and $95 \%$ of current production, respectively), are expensive for the amount of hydrogen produced and often require initial capital expenditures exceeding several million dollars. In addition, transport and storage costs are high, requiring large, heavy tanks designated for hazardous materials transport by the US Department of Transportation. Devices that produce hydrogen via electrolysis at rates of $10-20 \mathrm{~L} / \mathrm{min}$ cost hundreds of thousands of dollars, the total cost of operation is high, and the resale values of the devices are low. These devices have limitations linked to large electricity draw, device complexity, and durability and lifetime of the PEM FCs, as well as comparative costs for production of each kilogram of hydrogen. Steam reformation, which allows for very high production rates, can only be conducted at massive, highly complex industrial-scale chemical plants that require direct sources of methane/natural gas and operate at very high temperatures and pressures.

However, there is an additional overriding problem with hydrogen production. As noted, much of the future increase in demand for hydrogen is based on the growing demand for clean transportation fuels, strict government regulations, and the focus on reducing $\mathrm{CO}_{2}$ in the atmosphere. It is true that at point of use, hydrogen is a clean burning fuel whose only by-product is water. But since more than $95 \%$ of hydrogen is produced using fossil fuels, hydrogen is not really "clean and green," and electrolysis - the major hydrogen source other than reformation - is exceedingly inefficient, expensive, and energy-intensive. Experimental methods involving wind, solar, biomass, etc. are still far from being economic or commercially cost-competitive.

For example, California - the world's sixth largest economy - has implemented increasingly stringent $\mathrm{CO}_{2}$ reduction goals and renewable energy mandates, and these include rapidly increasing requirements for zero emissions hydrogen vehicles. However, hydrogen produced from fossil fuels - specifically natural gas - does not count toward achieving these goals, and is not eligible for California's lucrative low carbon fuel credits [8].

This is the $800 \mathrm{lb}$ gorilla in the room that hydrogen advocates and hydrogen industry promoters conveniently ignore: The hydrogen economy is hitting a brick wall that will severely limit its growth potential. All of the frenzied hype over hydrogen FCs, hydrogen vehicles, distributed power, clean fuels, sustainable generation, etc. is meaningless until a method can be found to efficiently and cheaply produce large quantities of hydrogen in a truly green and sustainable manner that does not increase $\mathrm{CO}_{2}$ emissions. Experimental methods involving bio-hydrogen production, renewable electrolysis, photo-electrochemical solar water splitting, solar high-temperature thermochemical cycles, high-temperature electrolysis, photo-biological, bioderived, microbial conversion, etc. are still far from being technically feasible, much less economic, or commercially cost-competitive.

More recently, sustainable hydrogen is being produced from scrap aluminum, and this represents a promising solution to the major problem confronting the hydrogen economy. This process is capable of producing significant amounts of high-purity hydrogen at a competitive cost per relevant unit in a scalable, controllable, and sustainable manner. It is effectively a third viable hydrogen production 
method - in comparison to reformation and electrolysis. Sustainable hydrogen production from scrap aluminum can thus provide the long-sought solution to the major environmental problem confronting the hydrogen economy [9].

\section{Review of previous research}

The most definitive analysis of hydrogen economy jobs was conducted by the US Department of Energy (DOE), which estimated the employment impacts of a transformation of the US economy to the use of hydrogen between 2020 and 2050 [10]. This study found that training for new skills may be needed across a wide spectrum of industries and that training and retraining programs may be needed to help ensure that the US workforce possesses appropriate skills and that sufficient numbers of trained personnel are available to support the hydrogen economy. However, the report made no attempt to identify emerging occupations and corresponding training and educational requirements and earnings.

A subsequent DOE report found that existing and emerging FC applications hold large job growth potential and that as various FC applications gain market share, the industry is expected to undergo significant growth [11]. It noted that "As market demand for hydrogen and fuel cell technologies increases across sectors of our economy, there will be an increasing need for trained and experienced personnel and accompanying services such as qualified maintenance technicians, installers, manufacturing professionals, trainers, insurers, and educators" [11]. Unfortunately, the Department's "comprehensive" US energy and employment reports barely even mention hydrogen or FC jobs [12].

A study by the American Solar Energy Association and Management Information Services, Inc. (ASEA/MISI) found that widespread hydrogen energy and FC market penetration could create nearly 1 million new jobs in the United States by $2030[13,14]$. It also determined that the jobs created are disproportionately for highly skilled, wellpaid, technical and professional workers, who provide the foundation for entrepreneurship and economic growth. However, it did not disaggregate hydrogen occupations.

More recently, DOE has developed models for estimating the job impacts of FCs and hydrogen:

- JOBS FC is a spreadsheet model that that allows users to estimate economic impacts from the manufacture and use of select types of FCs [15].

- JOBS H2 is a spreadsheet model that allows users to estimate economic impacts from the development and operation of select types of hydrogen fueling stations [16].

DOE has used these models to estimate the economic impact of FC deployment in forklifts and for backup power under the American Recovery and Reinvestment Act [17] and the economic impacts associated with commercializing FC electric vehicles in California [18]. However, these analyses did not disaggregate jobs by skill, education, or earnings, and the JOBS FC and JOBS H2 models do not permit such disaggregation.

Thus, while these studies forecast that about 700,000 to 1 million new hydrogen energy and FC jobs may be created over the next decade, the reports do not disaggregate the jobs into occupations or skills, identify education and training requirements, or indicate wage and salary levels. Here we have developed these necessary modifications. We derived these estimates primarily using the methodology developed in the ASEA/MISI study and refined in various subsequent analyses [19-21]. We revised these estimates to account for gaps in the information, to relate specifically to the $\mathrm{H}_{2}$ and $\mathrm{FC}$ industries, technologies, and sectors of interest here, and to represent average US salaries in 2016. A number of other changes were made to make this information useful and informative in assessing the hydrogen economy and jobs.

\section{Findings}

Our results are summarized in Table 1, which shows examples of emerging jobs, salaries, and education and training requirements in the hydrogen and $\mathrm{FC}$ industries. As shown, wages and salaries in many sectors of the emerging $\mathrm{H}_{2}$, FC, and related industries are higher than the US averages. Although many high-tech industries almost exclusively require highly educated workers with masters or doctoral degrees, these emerging $\mathrm{H}_{2}$ and $\mathrm{FC}$ industries require a wide variety of occupations at all skill levels. Nevertheless, many occupations in these industries include jobs that require associate's degrees, long-term on-the-job training, or trade certifications - and lead to jobs that pay higher than US average wages.

Unlike some industries, the hydrogen and FC industries are feasible targets for job creation in many states and regions. With a wide diversity of required skills and continuing research into relevant technologies, communities can develop clusters around different sectors of the industries. However, states and cities must recognize that they will be in intense competition as communities throughout the United States compete for these emerging technologies and industries with traditional universitycentered research areas, including Palo Alto (Stanford University), Ann Arbor (University of Michigan), Trenton (Princeton University), Boston (Massachusetts Institute of Technology), Champaign-Urbana (University of Illinois), Austin (University of Texas), the Research Triangle in North Carolina, and other university-industry complexes. In addition, communities must compete for these jobs with traditional high-tech metropolitan areas like San Jose, Boston, and Washington, DC, along with metropolitan areas with rapidly expanding manufacturing, such as Grand Rapids, Michigan, Denver, Colorado, and Portland, OR.

We find that jobs will be created across a new continuum of employment, skills, responsibilities, and earnings. Notably, many of these jobs do not currently exist and do not have occupational titles defined in federal and state government occupational handbooks and employment guides. Further, many of these new jobs require different skills and education than current jobs, and training needs must be determined to enable this rapidly growing sector of the US economy and labor market to have a sufficient supply of trained and qualified employees. Eventually, most of these occupations will grow, the number of employees classified in the occupations will 
Table 1. Examples of emerging jobs, salaries, and education and training requirements in the hydrogen and fuel cell industries.

\begin{tabular}{|c|c|c|}
\hline Occupational title & Average salary $(2016 \$)$ & Minimum educational requirements \\
\hline Director of hydrogen energy development & $\$ 138,000$ & Bachelor's (Business) \\
\hline Hydrogen fueling station manager & $\$ 56,300$ & Bachelor's (CE) \\
\hline Hydrogen/fuel cell R\&D director & $\$ 129,000$ & Doctoral \\
\hline Hydrogen fuel cell system technician & $\$ 39,500$ & HSD/GED/OJT/TS/apprenticeship \\
\hline Junior hydrogen energy technician & $\$ 23,400$ & HSD/GED/OJT/TS/apprenticeship \\
\hline Fuel cell engineering intern & $\$ 6,800$ & HSD/GED/OJT/apprenticeship \\
\hline Fuel cell manufacturing technician & $\$ 45,650$ & Associate's \\
\hline Fuel cell fabrication and testing technician & $\$ 45,800$ & Associate's \\
\hline $\begin{array}{l}\text { Hydrogen power plant installation, operations, } \\
\text { engineering, and management }\end{array}$ & $\$ 69,700$ & Bachelor's (EE, ME, CE) \\
\hline Hydrogen energy systems designer & $\$ 47,900$ & Apprenticeship/TS \\
\hline Fuel cell plant manager & $\$ 90,500$ & Bachelor's (EE, ME) \\
\hline Hydrogen energy system operations engineer & $\$ 68,100$ & $\mathrm{HSD} / \mathrm{GED}$ \\
\hline Hydrogen fueling station designer \& project engineer & $\$ 74,200$ & Bachelor's (Engineer) \\
\hline Hydrogen fuel transporter - trucker & $\$ 36,950$ & OJT \\
\hline Hydrogen fueling station operator & $\$ 29,700$ & OJT \\
\hline Hydrogen fuels policy analyst \& business sales & $\$ 56,200$ & Bachelor's (Business) \\
\hline Hydrogen systems program manager & $\$ 73,220$ & Bachelor's (Engineer) \\
\hline Emissions accounting \& reporting consultant & $\$ 64,200$ & Bachelor's (various) \\
\hline Fuel cell quality control manager & $\$ 74,600$ & Master's (Science/Engineering) \\
\hline Hydrogen pipeline construction worker & $\$ 46,300$ & HSD/GED/OJT/TS/apprenticeship \\
\hline Fuel cell designer & $\$ 78,200$ & Master's (Science) \\
\hline Hydrogen energy engineer & $\$ 72,300$ & Bachelor's (Engineer) \\
\hline Fuel cell power systems engineer & $\$ 76,400$ & Master's (EE) \\
\hline Fuel cell fabrication technician & $\$ 23,150$ & HSD/GED/OJT/TS/apprenticeship \\
\hline Hydrogen systems \& retrofit designer & $\$ 90,600$ & Bachelor's \\
\hline Fuel cell retrofit installer & $\$ 41,600$ & HSD/GED/OJT/TS apprenticeship \\
\hline Fuel cell retrofit manufacturer plant labor & $\$ 36,500$ & $\mathrm{HSD} / \mathrm{GED}$ \\
\hline Hydrogen vehicle electrician & $\$ 44,800$ & HSD/GED/OJT/TS apprenticeship \\
\hline Fuel cell vehicle development engineer & $\$ 69,800$ & Bachelor's (Engineer) \\
\hline Hydrogen systems safety investigator - cause analyst & $\$ 88,350$ & Bachelor's (various) \\
\hline Hydrogen lab technician & $\$ 40,600$ & Associate's \\
\hline Hydrogen energy system installer helper & $\$ 23,200$ & $\mathrm{HSD} / \mathrm{GED}$ \\
\hline Hazardous materials management specialist & $\$ 55,300$ & Bachelor's (Science) \\
\hline Hydrogen energy system installer & $\$ 31,500$ & HSD/GED/OJT/TS apprenticeship \\
\hline Fuel cell power systems operator and instructor & $\$ 50,900$ & HSD/GED/OJT/TS apprenticeship \\
\hline Fuel cell backup power system technician & $\$ 40,200$ & HSD/GED/OJT/TS apprenticeship \\
\hline Senior automotive fuel cell power electronics engineer & $\$ 69,700$ & Bachelor's (EE) \\
\hline Emissions reduction credit portfolio manager & $\$ 47,400$ & Bachelor's (Business) \\
\hline Emissions reduction project developer specialist & $\$ 63,450$ & Bachelor's (various) \\
\hline Emissions reduction project manager & $\$ 78,600$ & Bachelor's (various) \\
\hline Hydrogen systems sales consultant & $\$ 53,800$ & Bachelor's (Business) \\
\hline Hydrogen plant operations manager & $\$ 95,200$ & Bachelor's (EE, ME) \\
\hline
\end{tabular}

Source: Cavendish Energy LLC. 
increase, and federal and state governments will add them to the employment classifications. Until then, labor market and employment analysis and forecasting will be performed using the current set of US Labor Department occupational titles and job descriptions. ${ }^{1}$ In the meantime, we have developed the methodology and database discussed here.

Table 1 identifies by occupational title some of the new jobs that we estimate will be created in the expanding hydrogen energy economy. ${ }^{2}$ Emerging occupational titles are listed in the first column of the table. The average US salary, listed in the second column, reflects the average 2016 salary for that occupation. ${ }^{3}$ Wages may be $15-20 \%$ lower at the beginning of employment and may rise to a level 15-20\% higher as the worker becomes an experienced employee. Furthermore, earnings are usually much higher in urban areas than in rural areas and in some other regions especially coastal cities such as New York, Boston, Washington, DC, Los Angles, Seattle, and San Francisco.

The third column gives the minimum recommended education required to gain entry into the occupation, and a required degree is identified for the advanced educational requirements. Employers will not always adhere to these recommendations, but this information can be useful to policymakers and workforce planners in providing an indication of the skills that firms are seeking in an applicant. Note that the education requirements listed include HSD/GED/OJT (high school degree, General Education Development, or on-the-job training), and Apprenticeship/TS (trade school) to a Master's degree. With the advanced (Bachelor's degree and higher) college requirements, typical abbreviations were used to identify the degree: $\mathrm{CE}, \mathrm{ME}, \mathrm{EE}$ - for chemical, mechanical and electrical engineering degrees, etc. Also note that many jobs can be filled by a candidate with one of various related science or engineering degrees, and these are listed generically as such.

Table 1 identifies some of the emerging job opportunities and corresponding earnings and education/ training requirements in the emerging $\mathrm{H}_{2} / \mathrm{FC}$ economy. This table illustrates the following:

- Salaries differ substantially, from $\$ 20,000-\$ 25,000$ for various technicians to nearly $\$ 140,000$ for a director of hydrogen development.

- Educational requirements cover the range from apprenticeship/trade school and HSD/GED/OJT to advanced university degrees.

- Nevertheless, there are numerous jobs and education and training requirements, and many of the jobs do not require university degrees.

- Similar jobs in different parts of the industries have diverse earnings and education/training requirements.

\footnotetext{
${ }^{1}$ These are listed in the US Department of Labor, Bureau of Labor Statistics, Standard occupational classification. Available at https://www.bls.gov/soc/. Also see US Department of Labor, Bureau of Labor Statistics, Occupational outlook handbook. Available at https://www.bls.gov/ooh/.

${ }^{2}$ Estimates derived by Cavendish Energy from a variety of sources, as discussed. Available at www.cavendish-e.com

3 These salary and wage estimates have been adjusted to reflect average US 2016 salary and wage levels.
}

For example, a hydrogen lab technician requires an Associate Degree and earns a salary of nearly $\$ 41,000$, whereas a junior hydrogen energy technician may require only a HSD/GED and earn a salary of less than $\$ 25,000$.

- Similarly, a hydrogen plant operations manager with a Bachelor's Degree may earn more than $\$ 95,000$, whereas a senior automotive FC power electronics engineer with a Bachelor's Degree may earn less than $\$ 70,000$.

- There exist numerous career paths that allow employees with apprenticeship/TS and HSD/GED to earn relatively high salaries, such as hydrogen vehicle technician, FC power systems operator and instructor, FC backup power system technician, and hydrogen energy system operations engineer.

\section{Conclusions}

The bottom line is that growth in the hydrogen and FC sectors of the US economy will lead to vast new employment opportunities as businesses expand to serve growing markets and to meet new clean and sustainable energy requirements and mandates. ${ }^{4}$ We find that the hydrogen and FC industries will create a variety of new high-paying jobs, many of which take advantage of technical and manufacturing skills currently going unused as industry continues to undergo restructuring, and US states, regions and cities can recruit these emerging industries and companies.

Although many high-tech industries almost exclusively require highly educated workers with advanced degrees, as noted, the $\mathrm{H}_{2}$ and $\mathrm{FC}$ industries possess requirements for numerous types of occupations, experience, and skills. Many occupations in these industries include jobs that require associate's degrees, long-term on-the-job training, or trade certifications, including scientists, engineers, chemists, managers, and technicians, all of which pay higher than US average wages. Unlike some industries, the $\mathrm{H}_{2}$ and $\mathrm{FC}$ industries are a realistic target industry for job creation in most regions and states. With a wide variety of the required skills as well as ongoing research into $\mathrm{H}_{2}$ and FC technologies, communities can build clusters around different segments of the industries. The wide variety of entrance points to the $\mathrm{H}_{2}$ and $\mathrm{FC}$ industries makes this market easier to penetrate if regions can market their strengths in high-tech, research, education, manufacturing, IT, and energy.

Nevertheless, challenges remain, and here we identify five that are salient and that require additional research: - Forecasts of the numbers of new jobs created vary widely, and these have to be further refined to estimate the number of jobs openings that will occur, the types of jobs created, when they will occur, and where they will be located.

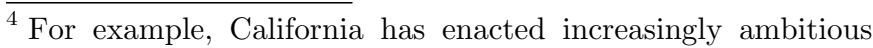
renewable energy portfolio standards and zero emission vehicles mandates, California Air Resources Board. Available at https:// www.arb.ca.gov/ html/factsheets/2030_renewables. pdf and https://www.arb.ca.gov/msprog/zevprog/zevprog.htm.
} 
- Here we identified 42 emerging occupations. This list must be expanded and updated as the $\mathrm{H}_{2}$ and $\mathrm{FC}$ industries mature.

- Training for new skills will be needed across a wide spectrum of industries. Some changes in skills are relatively well defined, but many likely changes remain difficult to forecast since many of the technologies are still evolving. Many job tasks currently remain unknown, and thus identification of training needs requires interactive research combined with job definition.

- Science and engineering education needs to change to prepare students for hydrogen and FC careers, and university and vocational programs need to be assessed to understand where opportunities lie and what additional curricula may be needed.

- Community colleges, technical schools, colleges, and universities need to be evaluated to determine how well they are preparing the workforce for the emerging hydrogen/FC economy and labor market.

The author is grateful to several anonymous referees for comments on an earlier draft of this paper.

\section{References}

1. D. Dietz, Fuel cells - almost here, Mater. Handl. Eng. 4 (1960)

2. US Energy Research and Development Administration, A national plan for energy research, development, and demonstration - creating energy choices for the future, ERDA 76-1, 1976

3. M. Bellis, Hydrogen fuel cells: innovation for the 21st century, 5, 2017. Available at https://www.thoughtco.com/ hydrogen-fuel-cells-1991799

4. T. Overton, K. Maize, Whatever happened to fuel cells? Power 5 (2017)

5. Global market for hydrogen fuel cell vehicles report 2017data \& forecasts 2015-2020, 2021-2026, and 2027-2032, Research and Markets, 6, 2017

6. R. Bezdek, Whatever happened to the hydrogen economy? World Oil 6, 23 (2018)

7. Hydrogen generation market worth 154.74 billion USD by 2022. Available at / / www.marketsandmarkets.com/MarketReports/hydrogen-generation-market-494.html
8. California Air Resources Board. Available at https://www.arb. ca.gov $/ \mathrm{html} /$ factsheets $/ 2030$ renewables.pdf and https:// www.arb.ca.gov/msprog/zevprog/zevprog.htm

9. The Cavendish Process will change the way the world generates hydrogen. Available at //www.cavendish-e.com/

10. Effects of a transition to a hydrogen economy on employment in the United States. Report to Congress by the US Department of Energy, 7, 2008

11. US Department of Energy, Fuel Cell Technologies Office, Careers in fuel cell technologies. Available at https://www1. eere.energy.gov/hydrogenandfuelcells/pdfs/green_jobs_ factsheet.pdf

12. US Department of Energy, USA energy and employment report, 1, 2017

13. American Solar Energy Association and Management Information Services, Inc., Defining, estimating, and forecasting the renewable energy and energy efficiency industries in the USA and in Colorado, America Solar Energy Society, 12, 2008

14. Management Information Services, Inc., Green collar jobs: economic drivers for the 21st century. Presented at the US Department of Energy, Washington, DC, 2, 2009

15. US Department of Energy, Argonne National Laboratory, JOBS FC model, 12, 2012. Available at https://jobsmodels. es.anl.gov/index.php?content $=\mathrm{fc}$

16. US Department of Energy, Argonne National Laboratory, JOBS H2 and JOBS NG model, 6, 2014. Available at https: / / jobsmodels.es.anl.gov/index.php?content $=\mathrm{h} 2$

17. US Department of Energy, Argonne National Laboratory, Economic impact of fuel cell deployment in forklifts and for backup power under the American Recovery and Reinvestment Act, 4, 2013

18. US Department of Energy, Argonne National Laboratory, Economic impacts associated with commercializing fuel cell electric vehicles in California: an analysis of the California road map using the JOBS H2 model, 12, 2014

19. American Solar Energy Association and Management Information Services, Inc., op. cit. See also Management Information Services, Inc., Development of economic and job impacts analysis tool and technology deployment scenario analysis. Report prepared for the US Department of Energy, National Energy Technology Laboratory, DOE/NETL-402/ 092509, 9, 2009

20. R. Bezdek, Economic and job forecasts for the sustainable energy industries in the USA, Int. J. Eng. Appl. Sci. 3, 50 (2016)

21. R. Bezdek, R. Wendling, The jobs impact of GHG reduction strategies in the USA, Int. J. Global Warming 6, 380 (2014)

Cite this article as: Roger H. Bezdek, The hydrogen economy and jobs of the future, Renew. Energy Environ. Sustain. 4, 1 (2019) 